\section{Agree With Behe}

\author{
S. Joshua Swamidass (D)
}

https://doi.org/10.54739/961u

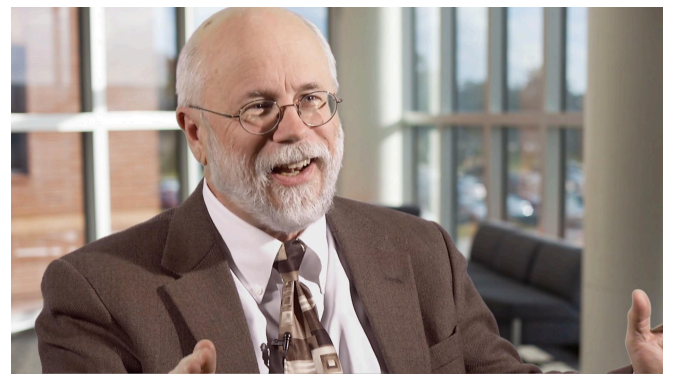

on the version of "design" visible in the sculptures of Mount Rushmore, but I am drawn to the divine design of Mount Everest. Likewise, I think it is important to affirm God's direct action in the world, but Behe has been coy about this affirmation. I am pleased, for this reason, that in this latest book he discusses "infusions" of information. Instead of this cryptic affirmation, I instead have argued that there is no evidence for or against the de novo creation of Adam, and there is no evidence for or against God's guidance of evolution.

Setting these minor difference, we both agree God designed us all. Even though Behe does not say this publicly, I'm sure he also believes God created everything, including Mount Everest. There is much common ground between.

\section{Rejecting Darwinism}

Behe rejects Darwinism. I agree with Behe, and reject Darwinism too. I am not a Darwinist. There are several meanings to the word "Darwinism." Both Behe and I reject Darwinism in all these many forms.

1. Darwinism can mean the ideology of atheism, including insistence that there are no supernatural beings or divine action. I agree with Behe in rejecting this ideology. Although I have many colleagues that are atheists, I personally reject atheism. I am, after all, a scientist that follows Jesus.

2. Darwinism can mean entirely naturalistic evolution, without allowing divine action. I'm not convinced by Behe's scientific

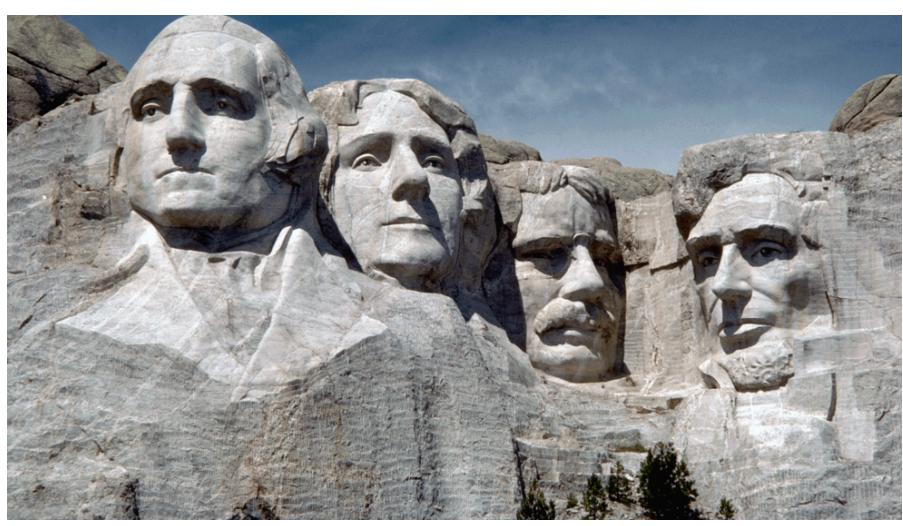

The Intelligent Design movement points to the sculptures on Mount Rushmore as an example of the design they hope to detect in Nature. The more I look at life, however, the less it looks like any human design. God created all of us, but we don\&rsquo; look like Mount Rushmore. We are far more grand than even the grandest human design. Life is more like Mount Everest. 
case for design, but I confess that God providentially governs all things. I believe God raised Jesus from the dead, so I know that $\mathrm{He}$ acts in the world. This is one reason, for example, I made a case for the de novo creation of Adam and Eve. Though science is silent about God's action, science does not deny it.

3. Darwinism can mean positive selection dominated evolutionary change, natural selection driven change. This version of evolution, the target of Behe's three books, was already shown inadequate in science by Kimura in 1968. Along with most biologists, I agree with Behe that Darwinism (in this sense) is not enough to account for all the complexity and beauty we see in life. We need non-Darwinian mechanisms too.

In all these senses, both Behe and I reject Darwinism. The Discovery Institute is mistaken when they referred to me as a Darwinist. Neither Behe nor I are Darwinists. We both reject Darwinism in all these forms.

I am pleased to report, also, that the Darwinian evolution Behe argues against (positive selection dominated change) was found inadequate in science a long time ago. As much as I enjoy his books, they are like entering a time warp. The version of evolution he argues against is antiquated, from another era. Evolutionary science moved on from strict-Darwinism a long time ago, to include a whole host of non-Darwinian mechanism. We know that non-Darwinian mechanisms are important in evolution, but Behe does not take them into account in his work. At some point, I will look forward to seeing how he responds to contemporary evolutionary science.

I've imagined how to extend his work, but many of the questions that arise seem well beyond the limits of science. Human's study of nature, after all, can only take us so far. Science does not make reference to God's action, but it does not deny it either. Perhaps God inspired mutations, or guided evolution in other ways. Science does not seem to tell us one way or another. Discerning the details of God's providence appears to be outside our view.

\section{Finding Greater Things}

I agree with Behe that there are greater things at stake than the approval of our peers. Paradoxically, Behe always advised me to keep

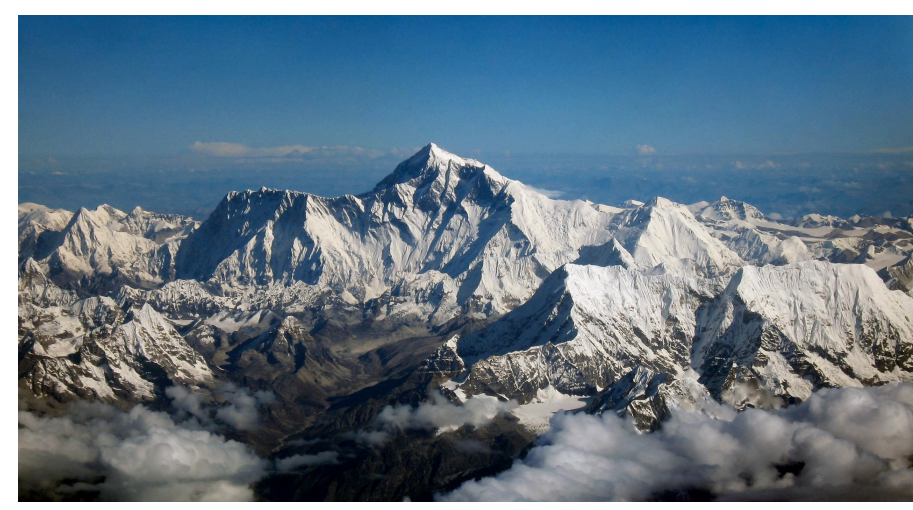

Majestic, dangerous, and looming beauty. Mount Everest calls us all into worship. God created all things, including this great mountain. Biology looks like Mount Everest to me: grand and totally beyond human ability. This is not the type of design with which the Intelligent Design movement is concerned, because it is not like the human design of Mount Rushmore. Everest, nonetheless, screams out to me, \&ldquo;God created all things!\&rdquo; I certainly detect God\&rsquo;s design here. Just like biology, Mount Everest is very little like a human design. quiet about my skepticism towards Darwinism till I was tenured. I deviated from his advice when I put forward the Genealogical Adam and Eve in 2017, before I had tenure. I had learned from him that some things are worth a professional cost. Sometimes we have to take risks. Fortunately, my colleagues were fair to me, and I still received tenure last summer.

As for me, I've been doing Veritas Forums around the country, even before tenure. At the Urbana Missions conference this year. I explained how God raised this man Jesus from the dead, and this is how I know that God exists, is good, and wants to be known. Whatever the consequences, may we truthfully explain how they encountered Jesus. Many of the students responded with trust to this invitation. There is a new sort of Christian in science rising now. This new generation wants a better way.

Behe also knows there are things greater than his professional career. He has paid a price for putting forward his scientific ideas. I wonder if he would share with us the more personal side of his story. In the end, Behe is a Christian, but I doubt the reason why is the Irreducible Complexity argument. I want to know more about how Behe came to know that there were greater things than the acceptance of his peers. I want to know how he encountered Jesus.

\section{Affirming Evolutionary Science}

There is more common ground between us. Alongside me, Behe affirms most of evolutionary science. In this, we are in very close agreement. There is an immense amount of evidence for an old earth and for the common descent of man with the great apes. In fact, it was reading Behe's books that helped convince me of common descent. Of course, he does not explain this evidence in depth in his book. One has to go elsewhere to see the evidence fully explained, but I'm indebted to his honest disclosures of what he had seen.

I know that many in the Church trust Behe, perhaps even more than they will ever trust me. I hope that Behe would consider explaining the evidence he has seen for common descent more directly to his

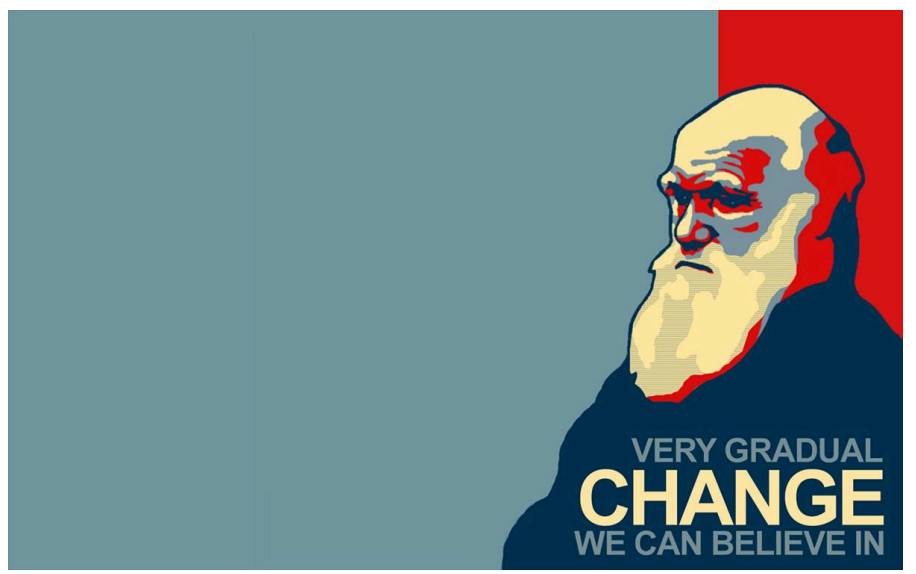

Earlier today, a young earth creationist blogged here that $<a$

href="https://peacefulscience.org/articles/darwin-day-2019/">we should consider retiring Darwin Day</a>. I agree. \&ldquo;Darwinism\&rdquo; creates a great deal of confusion in engaging the public about evolutionary science. I am not a Darwinist. Perhaps we need an \&ldquo; Evolution Day\&rdquo; instead. This Darwin Day poster is catchy, but is also emblematic of the problem. Evolutionary science has moved far beyond Darwinism. Darwin, for all his strengths, is a divisive figure. A more inclusive dialogue would place less focus on him. 
following. In doing so, he would do a great service to the Church, and for science.

\section{Come Let Us Reason}

There is more too. We both agree that the "bad design" argument is a bad argument.

Minor points aside, I find myself agreeing with Behe on most things.

When I read Behe's first book as an undergraduate student, I was totally convinced by his argument. It would be many years before $\underline{I}$ discovered that Irreducible Complexity was already a solved problem in biology (see Muller's Two-Step). Back then, I did not affirm evolutionary science; it would be many years before I came to agree with Behe on the evidence for common descent. At every point of my life, I agree with him on some points, and disagree on others. He has stayed the same, but I changed. Through my journey, even now, Behe always struck me as sincere, well-meaning, and brave. On Irreducible Complexity, he had a good idea. Like many good ideas, it did not pan out (at least in my assessment). Every scientist has ideas that do not past muster. At least Behe has been courageous enough bring his

\section{References}

https://peacefulscience.org/books/darwin-devolves/

https://en.wikipedia.org/wiki/Nathan_H._Lents

https://en.wikipedia.org/wiki/Richard_Lenski

https://blogs.sciencemag.org/books/2019/02/07/darwin-devolves

https://discourse.peacefulscience.org/t/_/4270/9

https://discourse.peacefulscience.org/t/_/4421

https://discourse.peacefulscience.org/t/_/4270

https://discourse.peacefulscience.org/t/_/4445

https://whyevolutionistrue.wordpress.com/2019/02/09/scientistsdamn-behes-new-book-he-responds-lamely

https://thehumanevolutionblog.com/2019/02/12/behe-polar-bears

https://discourse.peacefulscience.org/t/_/4473

https://discourse.peacefulscience.org/t/_/2998

https://peacefulscience.org/articles/much-to-discuss/

https://peacefulscience.org/books/darwins-black-box/ ideas forward. I respect him for this courage immensely. There is no shame in this.

In the end, I disagree with the argument in his current book, Darwin Devolves. Among scientists, debates like this are common and normal. Engaging his ideas more deeply, I would hope, could be a point of conversation and discussion between us. I look forward to seeing this conversation unfold. There have been a couple misfires from the Discover Institute this last week, but we can recover. As it stands, I agree even more with Behe now than ever.

I agree with Behe. I also disagree with him. Perhaps we will engage the great questions together at the Discovery Institute's Summer Workshop, if they will let me join them. I hope they do include me. Our disagreements are on the small things. Whether or not Behe's specific scientific argument is valid or not, come let us engage the grand questions together.

Dialogue with us about the grand questions. What is life? What is consciousness? Who are we? Where did we come from? Come reason with us.

https://peacefulscience.org/pdf/swamidass-confident-faith.pdf https://peacefulscience.org/articles/defense-tim-keller/ https://discourse.peacefulscience.org/t/_/1626

https://discourse.peacefulscience.org/t/_/662

https://peacefulscience.org/articles/darwin-day-2019/

https://peacefulscience.org/articles/genealogical-rapprochement/ https://peacefulscience.org/articles/peace-be-with-you/ http://veritas.org/evidence-easter-scientists-list https://discourse.peacefulscience.org/t/_/652 https://discourse.peacefulscience.org/t/_/554 https://peacefulscience.org/articles/evidence-and-evolution/ https://discourse.peacefulscience.org/t/_/1491

https://discourse.peacefulscience.org/t/_/662/6

https://discourse.peacefulscience.org/t/_/4435 